Article

\title{
Kinetics of Flavoenzyme-Catalyzed Reduction of Tirapazamine Derivatives: Implications for Their Prooxidant Cytotoxicity
}

\author{
Aušra Nemeikaitè-Čèniené ${ }^{1}$, Jonas Šarlauskas ${ }^{2}$ (), Violeta Jonušiené ${ }^{3}{ }^{(1)}$, Audronè Maroziené ${ }^{2}$, \\ Lina Misevičienè ${ }^{2}$, Aliaksei V. Yantsevich ${ }^{4}$ and Narimantas Čènas ${ }^{2, *}$ \\ 1 State Research Institute Center for Innovative Medicine, Santariškiu St. 5, LT-08406 Vilnius, Lithuania; \\ ausra.ceniene@imcentras.lt \\ 2 Department of Xenobiotics Biochemistry, Institute of Biochemistry of Vilnius University, Saulètekio 7, \\ LT-10257 Vilnius, Lithuania; jonas.sarlauskas@bchi.vu.lt (J.Š.); audrone.maroziene@bchi.vu.lt (A.M.); \\ lina.miseviciene@bchi.vu.lt (L.M.) \\ 3 Department of Biochemistry and Molecular Biology, Institute of Biosciences of Vilnius University, Saulètekio \\ 7, LT-10257 Vilnius, Lithuania; violeta.jonusiene@gf.vu.lt \\ 4 Institute of Bioorganic Chemistry, NAS of Belarus, Kuprevicha 5/2, BY-220072 Minsk, Belarus; \\ al.yantsevich@gmail.com \\ * Correspondence: narimantas.cenas@bchi.vu.lt; Tel.: +370-5-223-4392
}

Received: 6 August 2019; Accepted: 11 September 2019; Published: 17 September 2019

\begin{abstract}
Derivatives of tirapazamine and other heteroaromatic $N$-oxides $(\mathrm{ArN} \rightarrow \mathrm{O})$ exhibit promising antibacterial, antiprotozoal, and tumoricidal activities. Their action is typically attributed to bioreductive activation and free radical generation. In this work, we aimed to clarify the mechanism(s) of aerobic mammalian cell cytotoxicity of $\mathrm{ArN} \rightarrow \mathrm{O}$ performing the parallel studies of their reactions with NADPH:cytochrome P-450 reductase (P-450R), adrenodoxin reductase/adrenodoxin (ADR/ADX), and $\mathrm{NAD}(\mathrm{P}) \mathrm{H}$ :quinone oxidoreductase (NQO1); we found that in P-450R and ADR/ADX-catalyzed single-electron reduction, the reactivity of $\mathrm{ArN} \rightarrow \mathrm{O}(n=9)$ increased with their single-electron reduction midpoint potential $\left(E^{1} 7\right)$, and correlated with the reactivity of quinones. NQO1 reduced $\mathrm{ArN} \rightarrow \mathrm{O}$ at low rates with concomitant superoxide production. The cytotoxicity of $\mathrm{ArN} \rightarrow \mathrm{O}$ in murine hepatoma MH22a and human colon adenocarcinoma HCT-116 cells increased with their $E^{1}$, being systematically higher than that of quinones. The cytotoxicity of both groups of compounds was prooxidant. Inhibitor of NQO1, dicoumarol, and inhibitors of cytochromes P-450 $\alpha$-naphthoflavone, isoniazid and miconazole statistically significantly $(p<0.02)$ decreased the toxicity of $\operatorname{ArN} \rightarrow \mathrm{O}$, and potentiated the cytotoxicity of quinones. One may conclude that in spite of similar enzymatic redox cycling rates, the cytotoxicity of $\mathrm{ArN} \rightarrow \mathrm{O}$ is higher than that of quinones. This is partly attributed to $\mathrm{ArN} \rightarrow \mathrm{O}$ activation by NQO1 and cytochromes P-450. A possible additional factor in the aerobic cytotoxicity of $\mathrm{ArN} \rightarrow \mathrm{O}$ is their reductive activation in oxygen-poor cell compartments, leading to the formation of DNA-damaging species similar to those forming under hypoxia.
\end{abstract}

Keywords: tirapazamine; reductive activation; oxidative stress; cytotoxicity

\section{Introduction}

$\mathrm{N}$-oxides of 1,2,4-benzotriazine and quinoxaline $(\mathrm{ArN} \rightarrow \mathrm{O})$ frequently possess promising antibacterial, antiprotozoal, and tumoricidal activities, including their potential application in the treatment of hypoxic tumors ([1,2], and references therein). In most cases, their action is attributed to bioreductive activation and free radical generation. Among their representatives, the redox reactions of 3-amino-1,2,4-benzotriazine-1,4-dioxide (tirapazamine, TPZ) and its derivatives have been studied 
most comprehensively. TPZ (1) is enzymatically reduced in a single-electron way to a free radical (2), which forms DNA-damaging species under hypoxic conditions, namely, an oxidizing hydroxyl radical $(\mathrm{OH} \cdot)([3]$, and references therein), and/or a highly reactive benzotriazinyl radical (3) that abstracts a hydrogen atom from DNA ([2,4,5], and references therein) (Scheme 1). The nature of DNA-damaging species is still a matter of debate.

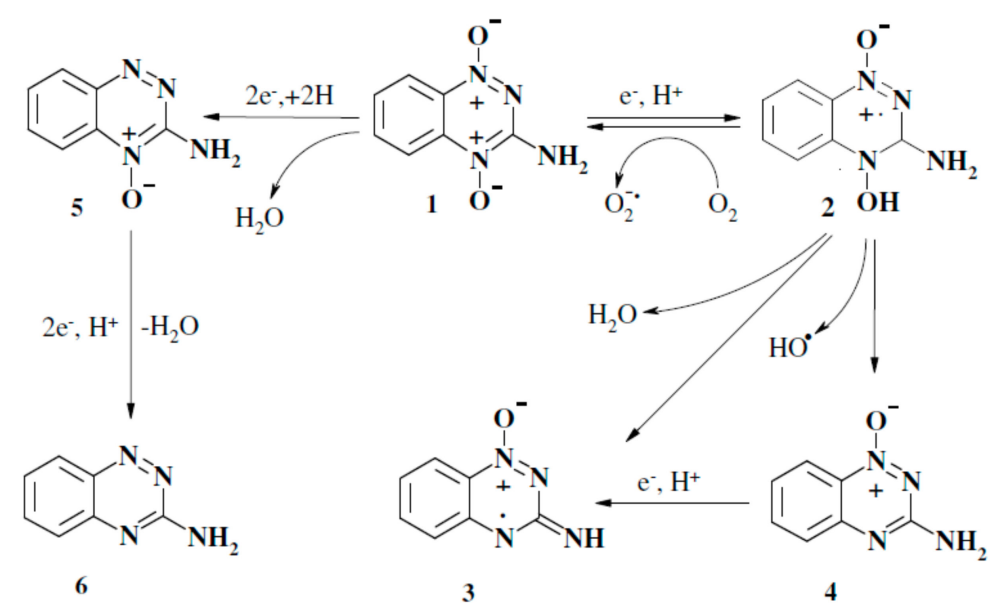

Scheme 1. Pathways of the reduction of tirapazamine in the cell.

In the cell, the final relatively nontoxic metabolites of TPZ are its mono- $N$-oxide (4), formed possibly via free radical (2) intermediate [2,3], and its nor-oxide (6), presumably formed via 4- $\mathrm{N}$-oxide (5) intermediate [6]. Their formation is strongly inhibited under oxic conditions. The single-electron reductive activation of TPZ under hypoxic and oxic conditions is carried out mainly by microsomal NADPH:cytochrome P-450 reductase (P-450R) ([7], and references therein), and/or by insufficiently characterized intranuclear NAD $(\mathrm{P}) \mathrm{H}$-oxidizing flavoenzymes [8]. Flavoenzyme NAD(P)H:quinone oxidoreductase (DT-diaphorase, NQO1) also reduces TPZ into compounds (4) and (6), however, it is unclear whether it is involved in TPZ cytotoxicity [9-11]. The data about the involvement of cytochromes P-450 (P-450) in the reductive metabolism and cytotoxic action of TPZ are also controversial [11-17].

The aerobic cytotoxicity of TPZ and other aromatic $N$-oxides is attributed to their redox cycling (Scheme 1), leading to the formation of superoxide $\left(\mathrm{O}_{2}^{-\cdot}\right)$ and subsequent oxidative stress [1,2]. Because their aerobic cytotoxicity is lower than under hypoxia, it attracted relatively less attention ([18-20]. On the other hand, some TPZ analogues possess anticancer activity at micromolar concentrations even under oxic conditions [21,22]. Besides, the redox cycling events also may be important in the antimicrobial and antiparasitic action of TPZ analogs ([2,23-25], and references therein). However, the kinetic data on the enzymatic reduction of $\mathrm{ArN} \rightarrow \mathrm{O}$ are scarce and scattered, and their relationship with aerobic cytotoxicity of $\mathrm{ArN} \rightarrow \mathrm{O}$ is understood incomprehensively.

The aim of this work was to characterize the relation between the aerobic cytotoxicity of TPZ derivatives and their reactivity towards single-electron transferring P-450R, and another model system, adrenodoxin reductase/adrenodoxin (ADR/ADX). An 'outer-sphere' electron transfer model [26] was applied for the analysis of kinetic data. Taken together with further cytotoxicity studies, it revealed that the cytotoxicity of $\mathrm{ArN} \rightarrow \mathrm{O}$ was higher than that of quinones with similar redox properties. We found that this phenomenon is partly attributed to the action of NQO1 and P-450.

\section{Results}

\subsection{Enzymatic Single-Electron Reduction of Aromatic N-Oxides}

In this work, we used a number of aromatic $N$-oxides, whose single-electron reduction midpoint potentials $\left(E^{1} 7\right)$ vary between $-0.318 \mathrm{~V}$ and $-0.575 \mathrm{~V}[4,18,27]$ (Figure 1 ). We studied their reactions 
with P-450R, which plays the most important role in the single-electron reduction and redox cycling of quinones, nitroaromatics and, possibly, $\mathrm{ArN} \rightarrow \mathrm{O}$ in the mammalian cell [7]. As an additional model reaction, we studied the reduction of $\mathrm{ArN} \rightarrow \mathrm{O}$ by $\mathrm{Fe}_{2} \mathrm{~S}_{2}$ redox protein adrenodoxin (ADX). Flavoenzyme NADPH:adrenodoxin reductase (ADR) reduces quinones and nitroaromatics in single-electron way, however, these reactions are relatively slow and complicated by the NADPH substrate inhibition [28,29]. On the other hand, ADX stimulates quinone- and nitroreductase activity of ADR, eliminating the inhibition by NADPH and providing an alternative more efficient electron-transfer pathway via ADX $[28,29]$. The studies of ArN $\rightarrow$ O reduction by ADX are also important in view of possible but insufficiently characterized role of FeS redox proteins in the reductive activation of prooxidant drugs and xenobiotics.

(1)<smiles>[O-][n+]1cn[n+]([O-])c2ccccc21</smiles>

(3)<smiles>Nc1nc2ccccc2[n+]([O-])n1</smiles>

(2)<smiles>[R]c1ccc2c(c1)[n+]([O-])nc(N)[n+]2[O-]</smiles>

(4)<smiles>[O-][n+]1cc[n+]([O-])c2ccccc21</smiles>

$\mathbf{R}=-\mathbf{H}$ $\mathrm{R}=-\mathbf{-} \mathrm{H}_{3}$; $\mathrm{R}=-\mathrm{OC}_{2} \mathrm{H}_{5}$ $\mathrm{R}=-\mathbf{C l}$; $\mathrm{R}=-\mathrm{F}$; $\mathrm{R}=-\mathrm{CF}_{3}$;

Figure 1. Formulae of aromatic $N$-oxides used in this work: 1,2,4-benzotriazine-1,4-dioxide (1), 3-amino-1,2,4-benzotriazine-1,4-dioxide (TPZ) and its derivatives (2), 3-amino-1,2,4-benzotriazine-1-oxide (3), and quinoxaline-1,4-dioxide (4).

The bimolecular rate constants $\left(k_{\text {cat }} / K_{\mathrm{m}}\right)$ of reduction of $\mathrm{ArN} \rightarrow \mathrm{O}$ by P450R and ADR/ ADX are given in Table 1. For the most active oxidants of P-450R, 7- $\mathrm{CF}_{3^{-}}$, 7-F-, and 7-Cl-substituted TPZ, and 1,2,4-benzotriazine-1,4-dioxide (Table 1), the $k_{\text {cat }}$ at their saturating concentrations were in the range of $17.0-19.0 \mathrm{~s}^{-1}$, i.e., close to $50 \%$ of the rate of cytochrome $c$ reduction by P-450R. In other cases, the reaction rates were proportional to the concentration of compounds up to the limits of their solubility, $\geq 600 \mu \mathrm{M}$. The $k_{\text {cat }}$ of $\mathrm{ArN} \rightarrow \mathrm{O}$ in ADR/ADX-catalyzed reactions were in the range of 3.7-3.3 s ${ }^{-1}$, which again was close to $50 \%$ of ADX- mediated cytochrome $c$ reduction rate. In both P450R- and ADR/ADX-catalyzed reactions, ArN $\rightarrow$ O undergo redox cycling, e.g., $100 \mu \mathrm{M}$ TPZ or its 7- $\mathrm{CF}_{3-}$ or 7-Cl- derivatives oxidized significant excess NADPH, $300 \mu \mathrm{M}$, and the NADPH oxidation was accompanied by $\mathrm{O}_{2}$ consumption proceeding with similar rate.

The increase of the reactivity of heteroaromatic $N$-oxides with their $E^{1}{ }_{7}$ values (Table 1 ) may be related to an 'outer-sphere' electron transfer mechanism [26]. In this case, the rate constant of single-electron transfer between reagents $\left(k_{12}\right)$ depends on the electron self-exchange rate constants of reagents $\left(k_{11}\right.$ and $\left.k_{22}\right)$ and equilibrium constant of the reaction $(K)\left(\log K=\Delta E^{1}(\mathrm{~V}) / 0.059\right.$, where $\Delta E^{1}$ is the difference in the standard single-electron transfer midpoint potential of reactants):

$$
k_{12}=\left(k_{11} \times k_{22} \times K \times f\right)^{1 / 2}
$$

and

$$
\log f=(\log K)^{2} / 4 \log \left(k_{11} \times k_{22} / Z^{2}\right.
$$

where $Z$ is a frequency factor $\left(10^{11} \mathrm{M}^{-1} \cdot \mathrm{s}^{-1}\right)$. In the reaction of electron donor with a series of homologous electron acceptors $\left(k_{22}=\right.$ constant), the Equation $(1,2)$ predict a parabolic (square) dependence of log $k_{12}$ on $\Delta E^{1}$ with a slope $\Delta \log k_{12} / \Delta \Delta E^{1}=8.45 \mathrm{~V}^{-1}$ at $\Delta E^{1}= \pm 0.15 \mathrm{~V}$. 
Table 1. The single-electron reduction midpoint potentials $\left(E^{1}{ }_{7}\right)$ of compounds and the steady-state bimolecular rate constants $\left(k_{\mathrm{cat}} / K_{\mathrm{m}}\right)$ of their reduction by P-450R and ADR/ADX.

\begin{tabular}{|c|c|c|c|c|}
\hline \multirow{2}{*}{ No. } & \multirow{2}{*}{ Compound } & \multirow{2}{*}{$E_{7}^{1}(\mathrm{~V})^{\mathrm{a}}$} & \multicolumn{2}{|c|}{$k_{\mathrm{cat}} / K_{\mathrm{m}}\left(\mathrm{M}^{-1} \cdot \mathrm{s}^{-1}\right)$} \\
\hline & & & P-450R & ADR/ADX \\
\hline & Aromatic $N$-oxides & & & \\
\hline 1 & 1,2,4-Benzotriazine-1,4-dioxide & -0.318 & $4.3 \pm 0.4 \times 10^{5}$ & $4.0 \pm 0.3 \times 10^{5}$ \\
\hline 2 & 7- $\mathrm{CF}_{3}$-tirapazamine & -0.345 & $8.7 \pm 0.7 \times 10^{4}$ & $1.9 \pm 0.2 \times 10^{5}$ \\
\hline 3 & 7-Cl-tirapazamine & -0.400 & $6.9 \pm 0.7 \times 10^{4}$ & $7.9 \pm 0.6 \times 10^{5}$ \\
\hline 4 & 7-F-tirapazamine & -0.400 & $3.4 \pm 0.3 \times 10^{4}$ & $5.2 \pm 0.6 \times 10^{5}$ \\
\hline 5 & Tirapazamine & -0.455 & $1.1 \pm 0.1 \times 10^{4}$ & $1.0 \pm 0.1 \times 10^{5}$ \\
\hline 6 & 7- $\mathrm{CH}_{3}$-tirapazamine & -0.474 & $8.6 \pm 0.7 \times 10^{3}$ & $1.2 \pm 0.1 \times 10^{5}$ \\
\hline 7 & 7- $\mathrm{C}_{2} \mathrm{H}_{5} \mathrm{O}$-tirapazamine & -0.494 & $4.5 \pm 0.5 \times 10^{3}$ & $1.5 \pm 0.1 \times 10^{5}$ \\
\hline 8 & 3-Amino-1,2,4-benzotriazine-1-oxide & -0.568 & $2.8 \pm 0.2 \times 10^{3}$ & $7.2 \pm 0.8 \times 10^{3}$ \\
\hline 9 & $\begin{array}{c}\text { Quinoxaline-1,4-dioxide } \\
\text { Quinones }\end{array}$ & -0.575 & $3.3 \pm 0.2 \times 10^{3}$ & $1.9 \pm 0.2 \times 10^{4}$ \\
\hline 10 & 5-Hydroxy-1,4-naphthoquinone & -0.090 & $1.5 \pm 0.1 \times 10^{7}$ & $5.6 \pm 0.6 \times 10^{6}$ \\
\hline 11 & 5,8-Dihydroxy-1,4-naphthoquinone & -0.110 & $1.8 \pm 0.1 \times 10^{7}$ & $1.1 \pm 0.1 \times 10^{7}$ \\
\hline 12 & 9,10-Phenanthrene quinone & -0.120 & $1.5 \pm 0.2 \times 10^{7}$ & $6.1 \pm 0.5 \times 10^{6}$ \\
\hline 13 & 1,4-Naphthoquinone & -0.150 & $1.1 \pm 0.1 \times 10^{7}$ & $4.0 \pm 0.3 \times 10^{6}$ \\
\hline 14 & 2-Methyl-1,4-naphthoquinone & -0.200 & $4.2 \pm 0.4 \times 10^{6}$ & $3.6 \pm 0.3 \times 10^{6}$ \\
\hline 15 & Tetramethyl-1,4-benzoquinone & -0.260 & $8.6 \pm 0.6 \times 10^{5}$ & $9.3 \pm 0.7 \times 10^{5}$ \\
\hline 16 & 1,8-Dihydroxy-9,10-anthraquinone & -0.325 & $1.2 \pm 0.3 \times 10^{5}$ & $6.0 \pm 0.7 \times 10^{5}$ \\
\hline 17 & 2-Hydroxy-1,4-naphthoquinone & -0.410 & $1.3 \pm 0.2 \times 10^{4}$ & $2.0 \pm 0.3 \times 10^{5}$ \\
\hline
\end{tabular}

This type of dependences frequently describes the single-electron reduction of quinones and nitroaromatics by flavoenzymes ([31,32], and references therein). To the best of our knowledge, the $k_{22}$ values for aromatic $\mathrm{N}$-oxides have not been experimentally determined. However, the value of $\log k_{22}$ $=8.59$ may be calculated using $\log k_{11}=2.65$ for $\mathrm{O}_{2} / \mathrm{O}_{2}{ }^{-\cdot}$ couple [33] from the rate constants of oxidation of quinoxaline-1,4-dioxide radicals with oxygen [5] (Appendix A). This shows that aromatic $\mathrm{N}$-oxides may possess high electron self-exchange rate which is close to that of another group of redox cycling compounds, quinones $\left(k_{22} \sim 10^{8} \mathrm{M}^{-1} \cdot \mathrm{s}^{-1}\right.$ [1]). This was experimentally confirmed by the determination of the rate constants of reduction of a series of quinones by P450R and ADR/ADX (Table 1). In both systems, $\operatorname{ArN} \rightarrow \mathrm{O}$ and quinones followed very close $\log k_{\text {cat }} / K_{\mathrm{m}}$ vs. $E^{1} 7$ relationships (Figure $2 \mathrm{~A}, \mathrm{~B}$ ). For this reason, quinones were used as the reference compounds in further cytotoxicity studies.

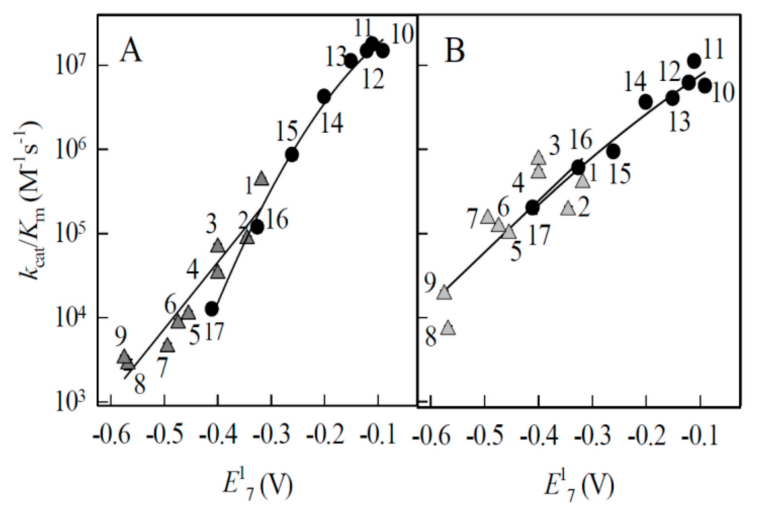

Figure 2. Dependences of bimolecular rate constants of enzymatic single-electron reduction of $\mathrm{ArN} \rightarrow \mathrm{O}$ and quinones on their single-electron reduction midpoint potential. (A) The reactivity of $\mathrm{ArN} \rightarrow 0$ (triangles) and quinones (circles) in P-450R-catalyzed reactions. (B) The reactivity of ArN $\rightarrow 0$ (triangles) and quinones (circles) in ADR/ADX-catalyzed reactions. The numbers of compounds correspond to those in Table 1 . The reactivity of $\mathrm{ArN} \rightarrow 0$ and quinones are described by the first order and second order polynomial regressions, respectively. 


\subsection{Studies of NQO1-Catalyzed Reduction of Aromatic N-Oxides}

Flavoenzyme NQO1 performs rapid NAD(P)H-dependent two-electron reduction of quinones into their hydroquinones ([34], and references therein). The reduction rate constants of quinones used in this work (Table 1) were determined previously [34]. Their $k_{\text {cat }}$ vary from $0.5 \mathrm{~s}^{-1}$ (1,8-dihydroxy-9,10-anthraquinone) to $10^{3} \mathrm{~s}^{-1}$ (tetramethyl-1,4-benzoquinone), and $k_{\text {cat }} / K_{\mathrm{m}}$ vary from $1.2 \times 10^{6} \mathrm{M}^{-1} \cdot \mathrm{s}^{-1}$ (1,8-dihydroxy-9,10-anthraquinone) to $5.4 \times 10^{8} \mathrm{M}^{-1} \cdot \mathrm{s}^{-1}$ (1,4-naphthoquinone). Apart from the reduction potential, the specificity of NQO1 strongly depends on the structure of oxidants, whose requirements are incompletely characterized at this time [34-36]. For example, another group of prooxidant compounds, nitroaromatics, are reduced $10^{2}-10^{5}$ times slower than quinones ([35], and references therein). In line with previous observations [9], heteroaromatic $N$-oxides used in this work were slow substrates for NQO1 (Table 2). The control experiments using NADPH regeneration system demonstrated that the reduction of $\mathrm{ArN} \rightarrow \mathrm{O}$ was responsible for not more than $5-10 \%$ of total $340 \mathrm{~nm}$ absorbance changes in the reaction course. Thus, NADPH oxidation rates measured at $340 \mathrm{~nm}$ could be taken as accurate within these limits.

Table 2. The single-electron reduction midpoint potentials $\left(E^{1}{ }_{7}\right)$ of aromatic $N$-oxides and the steady-state rate constants of their reduction by NQO1.

\begin{tabular}{|c|c|c|c|c|}
\hline No. & Compound & $E^{1}{ }_{7}(\mathrm{~V})$ & $k_{\text {cat }}\left(\mathrm{s}^{-1}\right)$ & $k_{\text {cat }} / K_{\mathrm{m}}\left(\mathrm{M}^{-1} \cdot \mathrm{s}^{-1}\right)$ \\
\hline 1 & 1,2,4-Benzotriazine-1,4-dioxide & -0.318 & $1.0 \pm 0.10$ & $5.1 \pm 0.7 \times 10^{3}$ \\
\hline 2 & 7- $\mathrm{CF}_{3}$-tirapazamine & -0.345 & $1.3 \pm 0.10$ & $3.7 \pm 0.4 \times 10^{3}$ \\
\hline 3 & 7-Cl-tirapazamine & -0.400 & $1.0 \pm 0.10$ & $4.3 \pm 0.4 \times 10^{3}$ \\
\hline 4 & 7-F-tirapazamine & -0.400 & $0.7 \pm 0.10$ & $4.9 \pm 0.6 \times 10^{3}$ \\
\hline 5 & Tirapazamine & -0.455 & $0.2 \pm 0.03$ & $2.4 \pm 0.2 \times 10^{3}$ \\
\hline 6 & 7- $\mathrm{CH}_{3}$-tirapazamine & -0.474 & $0.3 \pm 0.05$ & $1.7 \pm 0.1 \times 10^{3}$ \\
\hline 7 & 7- $\mathrm{C}_{2} \mathrm{H}_{5} \mathrm{O}$-tirapazamine & -0.494 & $0.3 \pm 0.04$ & $1.0 \pm 0.1 \times 10^{3}$ \\
\hline 8 & 3-Amino-1,2,4-benzotriazine-1-oxide & -0.568 & $0.1 \pm 0.02$ & $1.6 \pm 0.2 \times 10^{3}$ \\
\hline 9 & Quinoxaline-1,4-dioxide & -0.575 & $0.6 \pm 0.10$ & $7.9 \pm 0.9 \times 10^{3}$ \\
\hline
\end{tabular}

The $k_{\text {cat }}$ for TPZ reduction (Table 2) expressed in moles NADPH oxidized per mole of enzyme per second, was close to previously reported value [8]. The rate of TPZ disappearance was equal to 20-25\% NADPH oxidation rate (Figure 3). In parallel, TPZ stimulated NADPH:cytochrome $c$ reductase activity of NQO1, which was partly inhibited by superoxide dismutase (Figure 3). For comparison, the rates of oxidation of NADPH and reduction of cytochrome $c$ by NQO1 in the presence of $50 \mu \mathrm{M}$ tetramethyl-1,4-benzoquinone were equal to $720 \pm 30 \mathrm{~s}^{-1}$ and $1400 \pm 52 \mathrm{~s}^{-1}$, respectively. In the presence of superoxide dismutase, the rate of reduction of cytochrome $c$ was almost unchanged, $1415 \pm$ $60 \mathrm{~s}^{-1}$.

\subsection{Studies of Cytotoxicity of Aromatic N-oxides}

In cytotoxicity studies, we determined the concentrations of $\mathrm{ArN} \rightarrow \mathrm{O}$ for $50 \%$ cell survival $\left(\mathrm{cL}_{50}\right)$ in murine hepatoma MH22a cells, and, in some cases, their concentrations for $50 \%$ of maximal inhibition $\left(\mathrm{GI}_{50}\right)$ of proliferation of human colon adenocarcinoma HCT-116 cells (Table 3). 


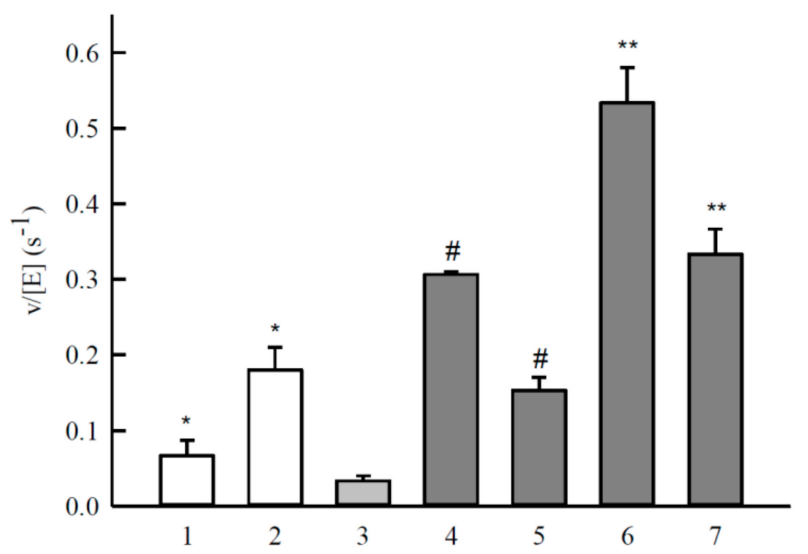

Figure 3. $\mathrm{NAD}(\mathrm{P}) \mathrm{H}$ :quinone oxidoreductase (NQO1)-catalyzed redox cycling of TPZ. The rates of NQO1-catalyzed oxidation of NADPH $(1,2)$, depletion of TPZ (3), and reduction of cytochrome $c(4-7)$ in the presence of $300 \mu \mathrm{M}$ NADPH. Additions: NADPH (1), NADPH + $300 \mu \mathrm{M}$ TPZ (2,3), NADPH + $50 \mu \mathrm{M}$ cytochrome $c$ (4), NADPH + cytochrome $c+100 \mathrm{U} / \mathrm{mL}$ SOD (5), NADPH + TPZ + cytochrome $c$ (6), NADPH + TPZ + cytochrome $c+\operatorname{SOD}(7), n=3, p<0.02$ for 1 against $2\left(^{*}\right)$, for 4 against 5 (\#), and 6 against $7(* *)$.

Table 3. The single-electron reduction midpoint potentials $\left(E^{1} 7\right)$, octanol/water distribution coefficients at $\mathrm{pH} 7.0(\log D)$ of compounds, their concentrations for $50 \%$ cell survival $\left(\mathrm{cL}_{50}\right)$ in murine hepatoma MH22a cells, and in their concentrations causing 50\% maximal proliferation inhibition $\left(\mathrm{GI}_{50}\right)$ of human colon adenocarcinoma HCT-116 cells.

\begin{tabular}{|c|c|c|c|c|c|}
\hline No. & Compound & $E_{7}^{1}(\mathrm{~V})$ & $\log D$ & $\begin{array}{c}\mathrm{cL}_{50}(\mu \mathrm{M}) \\
\mathrm{MH} 22 \mathrm{a}\end{array}$ & $\begin{array}{c}\mathrm{GI}_{50}(\mu \mathrm{M}) \\
\mathrm{HCT}-116\end{array}$ \\
\hline & Aromatic $N$-oxides & & & & \\
\hline 1 & 1,2,4-Benzotriazine-1,4-dioxide & -0.318 & -0.70 & $11 \pm 1.5$ & n.d. \\
\hline 2 & $7-\mathrm{CF}_{3}$-tirapazamine & -0.345 & 0.76 & $3.4 \pm 0.4$ & $6.0 \pm 1.0$ \\
\hline 3 & 7-Cl-tirapazamine & -0.400 & 0.49 & $3.1 \pm 0.5$ & $13 \pm 1.5$ \\
\hline 4 & 7-F-tirapazamine & -0.400 & 0.03 & $7.2 \pm 1.0$ & n.d. \\
\hline 5 & Tirapazamine & -0.455 & 0.11 & $31 \pm 5.5$ & $75 \pm 7.0$ \\
\hline 6 & 7- $\mathrm{CH}_{3}$-tirapazamine & -0.474 & 0.40 & $83 \pm 10$ & $50 \pm 6.0$ \\
\hline 7 & 7- $\mathrm{C}_{2} \mathrm{H}_{5} \mathrm{O}$-tirapazamine & -0.494 & 0.08 & $64 \pm 10$ & $60 \pm 7.0$ \\
\hline 8 & 3-Amino-1,2,4-benzotriazine-1-oxide & -0.568 & 0.30 & $\geq 600$ & $\geq 600$ \\
\hline 9 & $\begin{array}{c}\text { Quinoxaline-1,4-dioxide } \\
\text { Quinones }\end{array}$ & -0.575 & -0.90 & $325 \pm 40$ & n.d. \\
\hline 10 & 5-Hydroxy-1,4-naphthoquinone & -0.090 & 1.82 & $2.5 \pm 0.04^{\mathrm{a}}$ & $0.30 \pm 0.05$ \\
\hline 11 & 5,8-Dihydroxy-1,4-naphthoquinone & -0.110 & 2.19 & $0.58 \pm 0.05^{\mathrm{a}}$ & $0.25 \pm 0.04$ \\
\hline 12 & 9,10-Phenanthrene quinone & -0.120 & 2.92 & $\begin{array}{l}4.6 \pm 0.3^{\mathrm{a}} \\
3.9 \pm 0.4^{\mathrm{b}}\end{array}$ & $1.0 \pm 0.1$ \\
\hline 13 & 1,4-Naphthoquinone & -0.150 & 1.49 & $3.1 \pm 0.05^{\mathrm{a}}$ & $1.0 \pm 0.1$ \\
\hline 14 & 2-Methyl-1,4-naphthoquinone & -0.200 & 1.89 & $18 \pm 1.3^{\mathrm{a}}$ & $7.0 \pm 1.2$ \\
\hline 15 & Tetramethyl-1,4-benzoquinone & -0.260 & 2.61 & $\begin{array}{l}59 \pm 5.0^{\mathrm{a}} \\
50 \pm 5.0^{\mathrm{b}}\end{array}$ & $45 \pm 6.5$ \\
\hline 16 & 1,8-Dihydroxy-9,10-anthraquinone & -0.325 & 3.56 & $120 \pm 15^{a}$ & n.d. \\
\hline 17 & 2-Hydroxy-1,4-naphthoquinone & -0.410 & -0.52 & $\begin{array}{l}500 \pm 80^{\mathrm{a}} \\
430 \pm 60^{\mathrm{b}}\end{array}$ & $300 \pm 28$ \\
\hline
\end{tabular}

${ }^{\mathrm{a}}$ Taken from Ref. [37]. ${ }^{\mathrm{b}}$ This work.

In addition, the same cytotoxicity parameters for a number of quinones were determined (Table 3).

We found that the cytotoxicity of $\mathrm{ArN} \rightarrow \mathrm{O}$ and quinones in both cell lines increased with their $E^{1}{ }_{7}$, and that $\mathrm{ArN} \rightarrow \mathrm{O}$ were typically by one order of magnitude more cytotoxic than quinones (Figure 4 ). 

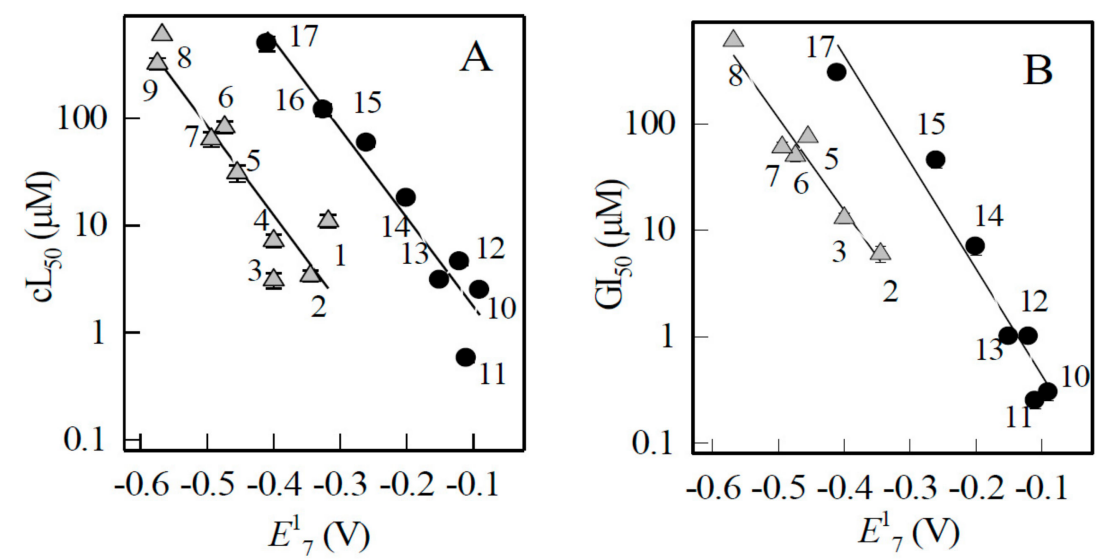

Figure 4. Dependence of cytotoxicity and growth inhibition potency of $\mathrm{ArN} \rightarrow \mathrm{O}$ and quinones on their single-electron reduction midpoint potential. (A) Cytotoxicity of $\mathrm{ArN} \rightarrow \mathrm{O}$ (triangles) and quinones (circles) in MH22a cells. (B) Growth inhibition potency of $\mathrm{ArN} \rightarrow \mathrm{O}$ (triangles) and quinones (circles) HCT-116 cells. The numbers of compounds correspond to those in Table 1 . The cytotoxicity and growth inhibition potency of $\mathrm{ArN} \rightarrow 0$ and quinones is described by the first order polynomial regressions.

The linear negative dependence of $\log \mathrm{cL}_{50}$ on $E^{1}{ }_{7}$ of quinones or nitroaromatics shows that the main factor of their cytotoxicity is redox cycling and oxidative stress ([38-40], and references therein), because, as a rule, the rates of single-electron reduction of these compounds increase with $E^{1}{ }_{7}$ of oxidant [31,32]. In accordance with this, the cytotoxicity of tirapazamine and 9,10-phenanthrene quinone in MH22a cells was decreased by desferrioxamine and the antioxidant $N, N^{\prime}$-diphenyl-p-phenylene diamine (DPPD), and enhanced by 1,3-bis(2-chloroethyl)-1-nitrosourea (BCNU), the latter inactivating glutathione reductase and depleting reduced glutathione [41] (Figure 5). The same effects of the above compounds were observed in the cytotoxicity studies of other randomly selected quinones and $\mathrm{ArN} \rightarrow \mathrm{O}$.

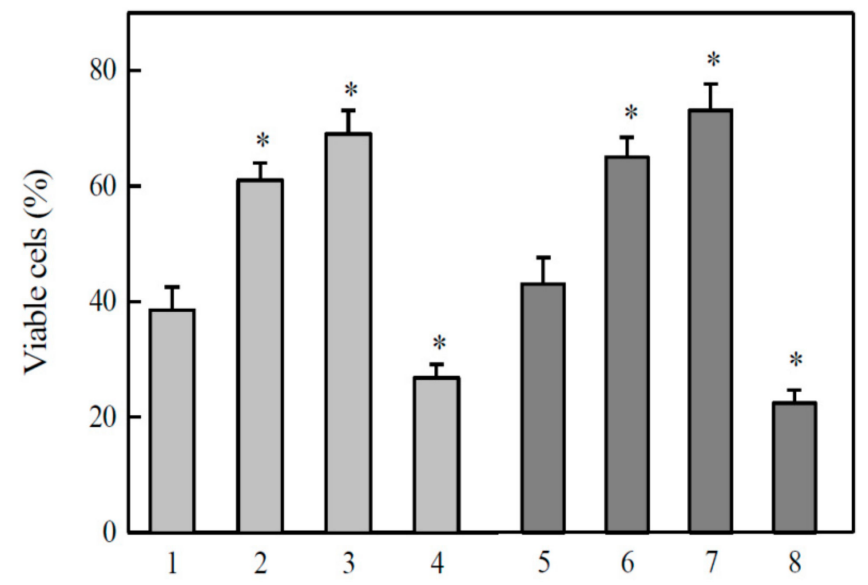

Figure 5. Effects of antioxidants and 1,3-bis(2-chloroethyl)-1-nitrosourea (BCNU) on the cytotoxicity of TPZ and 9,10-phenanthrene quinone in MH22a cells. $40 \mu \mathrm{M}$ TPZ (1-4), $5.0 \mu \mathrm{M}$ 9,10-phenanthrene quinone (5-8), additions: none $(1,5),+300 \mu \mathrm{M}$ desferrioxamine $(2,6),+3.0$ $\mu \mathrm{M}$ N,N'-diphenyl-p-phenylene diamine (DPPD) (3,7), + $20 \mu \mathrm{M}$ BCNU (4,8). Additions of DPPD, desferrioxamine and BCNU did not affect the cell viability. $n=3, p<0.02$ for 1 against $2-4$, and for 5 against $6-8\left({ }^{*}\right)$. Cell viability in control experiments, $98.5 \pm 1.0 \%$.

The enhanced cytotoxicity of $\mathrm{ArN} \rightarrow \mathrm{O}$ is not related to their high lipophilicity. In general, the calculated octanol/water distribution coefficients at $\mathrm{pH} 7.0(\log D)$ of $\mathrm{ArN} \rightarrow \mathrm{O}$ are lower than those of quinones (Table 3). Concerning other enzymatic mechanisms possibly enhancing the cytotoxicity of $\mathrm{ArN} \rightarrow \mathrm{O}$, the involvement of NQO1 and cytochromes P-450 is a matter of debate [9-17]. Here we studied 
the effects of NQO1 inhibitor, dicoumarol, and several inhibitors of cytochromes P-450 on the cytotoxicity of $\mathrm{ArN} \rightarrow \mathrm{O}$ and quinones. Dicoumarol potentiated the cytotoxicity of tetramethyl-1,4-benzoquinone and 9,10-phenanthrene quinone (Figure 6). On the other hand, it decreased the cytotoxicity of tirapazamine and its 7-F-derivative (Figure 6).

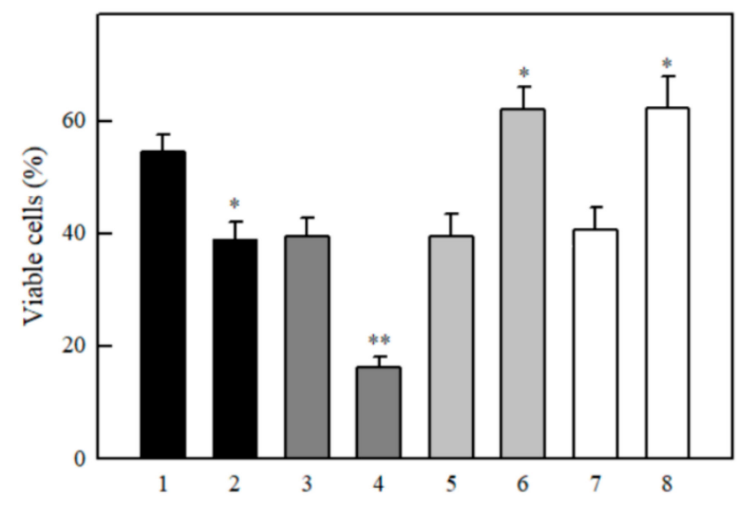

Figure 6. Effects of dicoumarol on the cytotoxicity of quinones and $\mathrm{ArN} \rightarrow \mathrm{O}$ in MH22a cells. $50 \mu \mathrm{M}$ tetramethyl-1,4-benzoquinone (1,2), $5.0 \mu \mathrm{M}$ 9,10-phenanthrene quinone (3,4), $50 \mu \mathrm{M} \mathrm{TPZ}(5,6), 10 \mu \mathrm{M}$ $7-F-T P Z ~(7,8)$ in the absence $(1,3,5,7)$ and in the presence of $20 \mu \mathrm{M}$ dicoumarol $(2,4,6,8)$. This dicoumarol concentration did not affect the cell viability in control experiments, 98.5-99.3\%. $n=3, p<0.02$ for 1 against 2,5 against 6 , and 7 against $8\left(^{*}\right), p<0.01$ for 3 against $4\left(^{* *}\right)$.

The inhibitors of cytochromes P-450 $\alpha$-naphthoflavone, isoniazide and miconazole enhanced the cytotoxicity of quinones (Figure 7A), and decreased the cytotoxicity of several randomly selected $\mathrm{ArN} \rightarrow \mathrm{O}$ (Figure 7B).

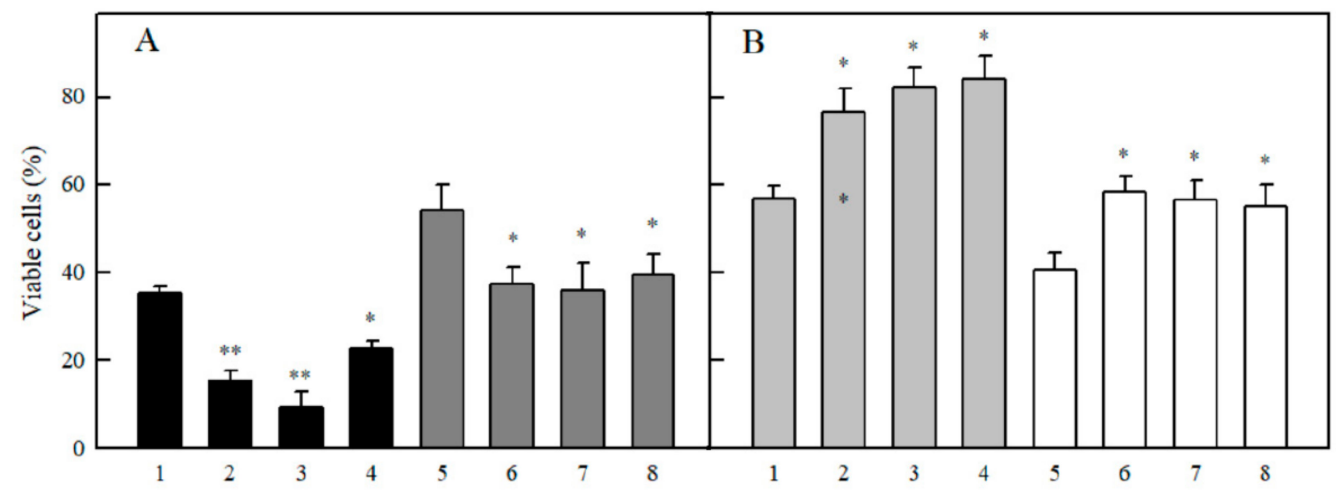

Figure 7. Effects of cytochrome P-450 inhibitors on the cytotoxicity of quinones and $\mathrm{ArN} \rightarrow \mathrm{O}$ in MH22a cells. (A) Cell viability in the presence of $5.0 \mu \mathrm{M} 9,10-$ phenanthrene quinone (1-4) and $50 \mu \mathrm{M}$ tetramethyl-1,4-benzoquinone (5-8), additions: none (1,5), +5.0 $\mu \mathrm{M} \alpha$-naphthoflavone $(2,6),+1.0 \mathrm{mM}$ isoniazid (3,7), + $5.0 \mu \mathrm{M}$ miconazole $(4,8) . n=3, p<0.01$ for 1 against $2,3\left(^{(* *}\right), p<0.02$ for 1 against 4 , and for 5 against $6-8\left(^{*}\right)$. (B) Cell viability in the presence of $10 \mu \mathrm{M}$ 1,2,4-benzotriazine-1,4-dioxide (1-4) and $10 \mu \mathrm{M}$ 7-F-TPZ (5-8), additions: none (1,5), +5.0 $\mu \mathrm{M} \alpha$-naphthoflavone $(2,6),+1.0 \mathrm{mM}$ isoniazid $(3,7),+5.0 \mu \mathrm{M}$ miconazole $(4,8) . n=3, p<0.02$ for 1 against $2-4$, and for 5 against $6-8\left(^{*}\right)$. Additions of $\mathrm{P}-450$ inhibitors did not affect the cell viability in control experiments, $98.5-99.3 \%$.

\section{Discussion}

The data of our work disclose several properties of heteroaromatic $\mathrm{N}$-oxides that are relevant to their cytotoxic/therapeutic action. First, in the context of a limited number of kinetic studies on flavoenzyme-catalyzed reactions involving TPZ derivatives and other $\mathrm{ArN} \rightarrow \mathrm{O}$, our study is the first application of the model of an 'outer-sphere' electron transfer for their single-electron reduction (Table 1 , Figure $2 \mathrm{~A}, \mathrm{~B})$. Their putative $k_{22}$ value, $\geq 10^{8} \mathrm{M}^{-1} \cdot \mathrm{s}^{-1}$, is consistent with $k_{22}$ of quinones and other 
planar aromatic electron donors, arenes [42]. This may be instrumental in guiding further studies on the activity of new $\mathrm{ArN} \rightarrow \mathrm{O}$ against bacteria, viruses, fungi and protozoa [22-24], and the prediction of their cytotoxicity/ therapeutic activity towards oxic tumours [21,22] on the basis of their kinetic data.

The most important finding of ours is that in spite of similar redox cycling rates (Figure 2) and lower lipophilicity (Table 3), aromatic $\mathrm{N}$-oxides were unexpectedly more cytotoxic than quinones (Figure 4). This phenomenon was observed in two cell lines. Evidently, the observed log (cytotoxicity) vs. $E^{1} 7$ relationships (Figure 4) reflect the superposition of redox cycling caused by single-electron transferring flavoenzymes, and other mechanisms that may oppositely influence the cytotoxicity of $\mathrm{ArN} \rightarrow \mathrm{O}$ and quinones.

First, let us discuss the additional mechanisms of quinone cytotoxicity. Although dicoumarol possesses several modes of action in the cell ([43], and references therein), our previous and current data show that in MH22a cells under our experimental conditions, it behaved as an NQO1 inhibitor: it decreased the cytotoxicity of aziridinyl-substituted quinones which stems from NQO1-catalyzed reductive activation [37], and increased the cytotoxicity of tetramethyl-1,4-benzoquinone and 9,10-phenanthrene quinone (Figure 6). In this case, NQO1 converts quinones into relatively stable hydroquinones that can be glucuronated or sulphonated and excreted from the cell ([44], and references therein). Further, it was shown that the inhibition of cytochromes P-450 augmented 2,3-dimethoxy-1,4-naphthoquinone-dependent NADPH oxidation in microsomes, and enhanced its toxicity in hepatocytes [45]. Authors suggest that the inhibition suppresses the electron transfer from P-450R to P-450, and accelerates the reduction of quinones by P-450R. Our data (Figure 7A) are in agreement with this viewpoint.

Concerning the additional mechanisms of cytotoxicity of $\mathrm{ArN} \rightarrow \mathrm{O}$, dicoumarol increased the cytotoxicity of TPZ in hepatocytes under low oxygen pressure, 1\% [11]. On the other hand, it protected against TPZ toxicity in A549 cells, besides, their TPZ-resistant subline almost completely lost NQO1 activity [10]. It was shown that oxygen partly inhibits the reductive metabolism of TPZ by isolated NQO1 [9]. In the presence of oxygen, NQO1 oxidized almost a 5-fold excess of NADPH per TPZ, which was explained by the formation of its 4- and 6-electron reduced metabolites [9]. Alternatively, this may also point to the redox cycling of TPZ radicals. Indeed, TPZ stimulated the superoxide dismutase-sensitive reduction of cytochrome $c$ by NQO1 (Figure 3), which supports this suggestion. NQO1 reduces quinones and most nitroaromatics in obligatory two-electron way, however, it also performs a single-electron reduction of nitroaromatic compound tetryl [46]. Thus, the dicoumarol protection against the cytotoxicity of TPZ derivatives (Figure 6) may be caused by the inhibition of NQO1-catalyzed redox cycling.

Our finding that cytochrome P-450 inhibitors protect against the cytotoxicity of TPZ derivatives (Figure $7 \mathrm{~B}$ ) is in line with the data on isoniazid protection against TPZ in hepatocytes under low oxygen pressure, $1 \%$ [11]. However, the nature of these phenomena is unclear. The role of cytochromes P-450 in the reductive metabolism of TPZ remains not elucidated, it was shown that CO and/or other P-450 inhibitors inhibited TPZ reduction in anaerobic microsomes [12,13] and anaerobic cell sonicates [14], although the absence of influence of $\mathrm{CO}$ on microsomal metabolism has also been demonstrated [15]. Besides, P-450 inhibitors metyparone and SKF-525 did not affect TPZ reduction in anaerobic hepatocytes [16], and CO and metyparone did not affect the intensity of ESR signal of TPZ radical in anaerobic microsomes [17]. It has been recently suggested that further progress in this area may be achieved by examining the involvement of $\mathrm{P}-450$ in possible aerobic $\mathrm{N}$-oxidation of nor-oxide metabolites of $\mathrm{ArN} \rightarrow \mathrm{O}$ [2].

In spite of uncertainty about the mechanism of action of P-450, our data show that NQO1 and $\mathrm{P}-450$ are at least partly responsible for higher cytotoxicity of $\mathrm{ArN} \rightarrow \mathrm{O}$ in comparison to quinones. One has to note that there exists another possible but currently poorly understood factor which may enhance the aerobic cytotoxicity of $\mathrm{ArN} \rightarrow \mathrm{O}$. According to recent estimation, during the metabolism of TPZ in aerobic tissue a small amount of DNA-damaging species similar to those forming under 
hypoxia, may be formed [2]. This side reaction may intensify during the reduction of $\mathrm{ArN} \rightarrow \mathrm{O}$ in the nucleus [8], which is poorly oxygenated [47].

Apart from clarifying the mechanisms of action of TPZ and its derivatives in the cell, our data may be helpful in the understanding of the reasons for their relatively high toxicity in vivo, and, possibly, its prediction. According to the scarce available data, TPZ derivatives are more toxic than quinones with similar $E^{1}{ }_{7}$ values, i.e., similar redox cycling activity. For intraperitoneal toxicity in mice, $\mathrm{LD}_{50}$ of 7-Cl-TPZ $\left(E^{1}{ }_{7}=-0.400 \mathrm{~V}\right)$, TPZ $\left(E^{1}{ }_{7}=-0.455 \mathrm{~V}\right)$, and $7-\mathrm{CH}_{3} \mathrm{O}-\mathrm{TPZ}\left(E^{1}{ }_{7}=-0.474 \mathrm{~V}\right)$ are equal to $0.2 \mathrm{mmol} / \mathrm{kg}, 0.5 \mathrm{mmol} / \mathrm{kg}$, and $1.0 \mathrm{mmol} / \mathrm{kg}$, respectively [48]. In contrast, a similar $\mathrm{LD}_{50}=0.09$ $\mathrm{mmol} / \mathrm{kg}$ is characteristic of 2-methyl-1,4-naphthoquinone with $E^{1}{ }_{7}=-0.200 \mathrm{~V}$ [49], whereas $\mathrm{LD}_{50}$ of 2-hydroxy-1,4-naphthoquinone $\left(E^{1}{ }_{7}=-0.410 \mathrm{~V}\right)$ is well above $3 \mathrm{mmol} / \mathrm{kg}$ [50].

\section{Materials and Methods}

\subsection{Enzymes and Chemicals}

Recombinant rat P-450R, bovine ADR and ADX were prepared as described in [51], their concentrations were determined according to $\varepsilon_{456}=21.4 \mathrm{mM}^{-1} \cdot \mathrm{cm}^{-1}, \varepsilon_{450}=11.0 \mathrm{mM}^{-1} \cdot \mathrm{cm}^{-1}$ and $\varepsilon_{414}$ $=10.0 \mathrm{mM}^{-1} \cdot \mathrm{cm}^{-1}$, respectively. NQO1 was prepared from rat liver according to Prochaska [52], its concentration was determined according to $\varepsilon_{460}=11.0 \mathrm{mM}^{-1} \cdot \mathrm{cm}^{-1}$. TPZ and other aromatic $N$-oxides were synthesized as described in $[4,18,27]$. The compound purity was characterized by IR and NMR spectrometry, melting point, and elemental analysis. NADPH, cytochrome $c$, superoxide dismutase, and other reagents were obtained from Sigma-Aldrich (St. Louis, MO, USA), and used as received.

\subsection{Enzymatic Assays}

The kinetic measurements were carried out spectrophotometrically using a PerkinElmer Lambda 25 spectrophotometer (PerkinElmer, Waltham, MA, USA) in $0.1 \mathrm{M}$ K-phosphate buffer ( $\mathrm{pH}$ 7.0) containing $1 \mathrm{mM}$ EDTA at $25^{\circ} \mathrm{C}$. The enzyme activities determined according to the rate of reduction of $50 \mu \mathrm{M}$ cytochrome $c\left(\Delta \varepsilon_{550}=20 \mathrm{mM}^{-1} \cdot \mathrm{cm}^{-1}\right)$ at substrate concentrations indicated below were close to those reported previously [29,31,34]: $39 \mathrm{~s}^{-1}(\mathrm{P}-450 \mathrm{R},[\mathrm{NADPH}]=100 \mu \mathrm{M}), 7.5 \mathrm{~s}^{-1}(\mathrm{ADR},[\mathrm{ADX}]=$ $0.5 \mu \mathrm{M},[\mathrm{NADPH}]=50 \mu \mathrm{M})$, and $1750 \mathrm{~s}^{-1}(\mathrm{NQO} 1,[\mathrm{NADPH}]=150 \mu \mathrm{M}$, [menadione] $=10 \mu \mathrm{M})$. In this case, $0.01 \%$ Tween 20 and $0.25 \mathrm{mg} / \mathrm{mL}$ bovine serum albumin were added as NQO1 activators. The initial rates of enzymatic NADPH-dependent $N$-oxide or quinone reduction were determined according to $\Delta \varepsilon_{340}=6.2 \mathrm{mM}^{-1} \cdot \mathrm{cm}^{-1}$ after the subtraction of intrinsic NADPH oxidase activities of enzymes, $0.05 \mathrm{~s}^{-1}$ (P-450R), $0.1 \mathrm{~s}^{-1}$ (NQO1), and $0.11 \mathrm{~s}^{-1}$ (ADR $+0.5 \mu \mathrm{M}$ ADX). The loss of TPZ during its reduction by NQO1 was monitored according to $\Delta \varepsilon_{465}=6.7 \mathrm{mM}^{-1} \cdot \mathrm{cm}^{-1}$. Preliminary findings indicate that 1-oxide and nor-oxide metabolites of TPZ do not absorb at this wavelength. The stock solutions of oxidants were prepared in DMSO (dilution factor 100). The values of turnover rate, $k_{\text {cat }}$, reflecting the maximal number of moles NADPH oxidized or oxidant reduced per mole of the enzyme active center per second, and $k_{\text {cat }} / K_{\mathrm{m}}$, the bimolecular rate constant (or catalytic efficiency constant), correspond to the inverse intercepts and slopes in Lineweaver-Burk coordinates, [E]/v vs. 1/[oxidant]. These rate constants were obtained by fitting the experimental data to the parabolic expression using the SigmaPlot 2000 (version 11.0, Systal Software, San Jose, CA, USA). In some experiments, as noted in the main text, NADPH regeneration system $(20 \mu \mathrm{M}$ NADPH, $10 \mathrm{mM}$ glucose-6-phosphate, and 0.3 $\mathrm{mg} / \mathrm{mL}$ glucose-6-phosphate dehydrogenase) was used. Oxygen consumption during the reactions was monitored using a Digital Model 10 Clark electrode (rank Brothers Ltd., Bottisham, UK).

\subsection{Cytotoxicity Assays}

Murine hepatoma MH22a cells obtained from Institute of Cytology of the Russian Academy of Sciences (St. Petersburg, Russia), were grown and maintained at $37^{\circ} \mathrm{C}$ in DMEM medium, supplemented with $10 \%$ fetal bovine serum, $100 \mathrm{U} / \mathrm{mL}$ penicillin and $0.1 \mathrm{mg} / \mathrm{mL}$ streptomycin, as described in [37]. In the cytotoxicity experiments, $3.0 \times 10^{4} / \mathrm{mL}$ cells were seeded on $18 \times 18 \mathrm{~mm}$ glass 
slides in 5-mL flasks either in the presence or in the absence of compounds, and were grown for $24 \mathrm{~h}$. In the absence of compounds, cells reached $40-50 \%$ confluence. Then, the slides were rinsed 3-4 times with phosphate buffered saline and stained with Trypan blue. The cells adherent to the slides were counted under a light microscope. Typically, they did not accumulate Trypan blue and their viability was 98.5-99.3\%. Human colon adenocarcinoma cells HCT-116 obtained from ATCC (Manassas, VA, USA), were grown and maintained at $37{ }^{\circ} \mathrm{C}$ in $5 \% \mathrm{CO}_{2}$ in RPMI 1640 DMEM medium, supplemented with $10 \%$ fetal bovine serum, $2 \mathrm{mM}$ L-glutamine and $0.05 \mathrm{mg} / \mathrm{mL}$ gentamycin. In the cytotoxicity experiments, $1.0 \times 10^{5} / \mathrm{mL}$ cells were seeded in the absence or in the presence of compounds, and were grown for $48 \mathrm{~h}$. In the absence of compounds, cells reached $65-75 \%$ confluence. Their viability was determined by staining with crystal violet [53]. Stock solutions of compounds were prepared in DMSO. Its concentration in cultivation media did not exceed $0.2 \%$, and did not affect cell viability. The experiments were conducted in triplicate.

\subsection{Statistical Analysis and Calculations}

The statistical analysis was performed using Statistica (version 4.3, Statsoft, Toronto, CA). Octanol/water distribution coefficients at $\mathrm{pH} 7.0(\log D)$ were calculated using $\log D$ Predictor (https://chemaxon.com).

Author Contributions: A.N.-Č. and V.J. performed the cytotoxicity studies, J.Š. synthesized compounds, A.M. and L.M. performed kinetic experiments and purified NQO1, A.V.Y. purified P-450R, ADR and ADX, N.Č. designed and supervised the experiments and wrote the manuscript.

Funding: This work was supported by the European Social Fund (Measure No. 09.33-LMT-K-712, grant No. DOTSUT-34/09.3.3.-LMT-K712-01-0058/LSS-600000-58).

Acknowledgments: We thank Mindaugas Lesanavičius for checking the stylistics of the manuscript.

Conflicts of Interest: The authors declare no conflict of interest. The funders had no role in the design of the study; in the collection, analyses, or interpretation of data; in the writing of the manuscript, or in the decision to publish the results.

\section{Abbreviations}

$\begin{array}{ll}\text { ADR } & \text { NADPH:adrenodoxin reductase } \\ \text { ADX } & \text { Adrenodoxin } \\ \text { ArN } \rightarrow \mathrm{O} & \text { Heteroaromatic } N \text {-oxide } \\ \text { BCNU } & 1,3 \text {-bis(2-chloroethyl)-1-nitrosourea } \\ \mathrm{CL}_{50} & \text { Concentration for } 50 \% \text { cell survival } \\ \mathrm{DPPD} & N_{,} N^{\prime} \text {-diphenyl-p-phenylene diamine } \\ E^{1} 7 & \text { Single-electron reduction midpoint potential } \\ \mathrm{GI}_{50} & \text { Concentration for } 50 \% \text { inhibition of maximal cell proliferation } \\ k_{\text {cat }} & \text { Catalytic constant } \\ k_{\text {cat }} / K_{\mathrm{m}} & \text { Bimolecular rate constant } \\ \text { LD } & \text { Median lethal dose } \\ \log D & \text { Octanol/water distribution coefficient at } \mathrm{pH} 7.0 \\ \mathrm{NQO} 1 & \text { NAD(P)H:quinone oxidoreductase } \\ \mathrm{P}-450 & \text { Cytochrome P-450 } \\ \mathrm{P}-450 \mathrm{R} & \text { NADPH:cytochrome P-450 reductase } \\ \mathrm{TPZ} & \text { Tirapazamine }\end{array}$

\section{Appendix A}

Calculation of electron self-exchange rate constant for heteroaromatic $\mathrm{N}$-oxides At $\Delta E^{1}=0$, Equation (1) may be expressed as

$$
\log k_{12}=\left(\log k_{11}+\log k_{22}\right) / 2
$$


For the calculation of electron self-exchange rate constant for heteroaromatic $N$-oxides, we use the rate constants of oxidation of radicals of 3,6,7-substituted 2-carboxy-4'-methylpiperazide- quinoxaline-1,4-dioxides by oxygen [5]. The reactivity of compounds decreases with their $E^{1}$ values, and is described by Equation (4):

$$
\log k_{12}=(4.92 \pm 0.15)-(4.52 \pm 0.31) \times E^{1}
$$

According to Equation (4), at $\Delta E^{1}=0$, i.e., at $E^{1}$ being equal to $-0.155 \mathrm{~V}$ (midpoint potential of $\mathrm{O}_{2} / \mathrm{O}_{2}{ }^{-}$. couple), $\log k_{12}=5.62$. Using $\log k_{22}=2.65$ for $\mathrm{O}_{2} / \mathrm{O}_{2}{ }^{-}$couple [33], we obtain $\log k_{11}=8.59$ for aromatic $N$-oxides.

\section{References}

1. Wardman, P.; Dennis, M.F.; Everett, S.A.; Patel, K.B.; Stratford, M.R.L.; Tracy, M. Radicals from one-electron reduction of nitro compounds, aromatic $N$-oxides and quinones: The kinetic basis for hypoxia-selective, bioreductive drugs. Biochem. Soc. Symp. 1995, 61, 171-194. [CrossRef] [PubMed]

2. Shen, X.; Gates, K.S. Enzyme-activated generation of reactive oxygen species from heterocyclic $N$-oxides under aerobic and anaerobic conditions and its relevance to hypoxia-selective prodrugs. Chem. Res. Toxicol. 2019, 32, 348-361. [CrossRef] [PubMed]

3. Shen, X.; Rajapakse, A.; Gallazzi, F.; Junnotula, V.; Fuchs-Knotts, T.; Glaser, R.; Gates, K.S. Isotopic labeling experiments that elucidate the mechanism of DNA strand cleavage by the hypoxia-selective antitumor agent 1,2,4-benzotriazine 1,4-di-N-oxide. Chem. Res. Toxicol. 2013, 22, 111-118. [CrossRef] [PubMed]

4. Shinde, S.S.; Maroz, A.; Hay, M.P.; Patterson, A.V.; Denny, V.A.; Anderson, R.F. Characterization of radicals formed following enzymatic reduction of 3-substituted analogues of the hypoxia-selective cytotoxin 3-amino-1,2,4-benzotriazine 1,4-dioxide (tirapazamine). J. Am. Chem. Soc. 2010, 132, 2591-2599. [CrossRef] [PubMed]

5. Anderson, R.F.; Yadav, P.; Shinde, S.S.; Hong, C.R.; Pullen, S.M.; Reynisson, J.; Wilson, W.R.; Hay, M.P. Radical chemistry and cytotoxicity of bioreductive 3-substituted quinoxaline di-N-oxides. Chem. Res. Toxicol. 2016, 29, 1310-1324. [CrossRef] [PubMed]

6. Fuchs, T.; Chowdhury, G.; Fuchs, C.L.; Gates, K.S. 3-Amino-1,2,4-benzotriazine 4-oxide: Characterization of a new metabolite arising from bioreductive processing of the antitumour agent 3-amino-1,2,4-benzotriazine 1,4-dioxide (tirapazamine). J. Org. Chem. 2001, 66, 107-114. [CrossRef] [PubMed]

7. Hunter, F.W.; Young, R.J.; Shalev, Z.; Vellanki, R.N.; Wang, J.; Gu, Y.; Joshi, N.; Sreebhavan, S.; Weinreb, J.; Goldstein, D.P.; et al. Identification of P450 oxidoreductase as a major determinant of sensitivity to hypoxia-activated prodrugs. Cancer Res. 2015, 75, 4211-4223. [CrossRef] [PubMed]

8. Delahoussaye, Y.M.; Evans, J.W.; Brown, J.M. Metabolism of tirapazamine by multiple reductases in the nucleus. Biochem. Pharmacol. 2001, 62, 1201-1209. [CrossRef]

9. Cahill, A.; Jenkins, T.C.; White, I.N.H. Metabolism of 3-amino-1,2,4-benzotriazine-1,4-dioxide (SR 4233) by purified DT-diaphorase under aerobic and anaerobic conditions. Biochem. Pharmacol. 1993, 45, 321-329. [CrossRef]

10. Elwell, J.H.; Siim, B.G.; Evans, J.W.; Brown, J.M. Adaptation of human tumor cells to tirapazamine under aerobic conditions. Implications of increased antioxidant enzyme activity to mechanism of aerobic cytotoxicity. Biochem. Pharmacol. 1997, 54, 249-257. [CrossRef]

11. Khan, S.; O'Brien, P.J. Molecular mechanisms of tirapazamine (SR 4233, WIN 59075)-induced hepatocyte toxicity under low oxygen concentrations. Br. J. Cancer 1995, 71, 780-785. [CrossRef] [PubMed]

12. Walton, M.I.; Workman, P. Enzymology of the reductive bioactivation of SR 4233. A novel benzotriazine di-N-oxide hypoxic cell cytotoxin. Biochem. Pharmacol. 1990, 39, 1735-1742. [CrossRef]

13. Riley, R.J.; Hemingway, S.A.; Graham, M.A.; Workman, P. Initial characterization of the major mouse cytochrome P450 enzymes involved in the reductive metabolism of the hypoxic cytotoxin 3-amino-1,2,4-benzotriazine-1,4-di-N-oxide (tirapazamine, SR 4233, WIN 59075). Biochem. Pharamacol. 1993, 45, 1065-1077. [CrossRef]

14. Wang, J.; Biedermann, K.A.; Wolf, C.R.; Brown, J.M. Metabolism of the bioreductive cytotoxin SR 4233 by tumour cells: Enzymatic studies. Br. J. Cancer 1993, 67, 321-325. [CrossRef] [PubMed]

15. Cahill, A.; White, I.N.H. Reductive metabolism of 3-amino-1,2,4-benzotriazine-1,4-dioxide (SR 4233) and the induction of unscheduled DNA synthesis in rat and human derived cell lines. Carcinogenesis 1990, 11, 1407-1411. [CrossRef] 
16. Silva, J.M.; O'Brien, P.J. Molecular mechanisms of SR 4233-induced hepatocyte toxicity under aerobic versus hypoxic conditions. Br. J. Cancer 1993, 68, 484-491. [CrossRef]

17. Lloyd, R.V.; Duling, D.R.; Rumyantseva, G.V.; Mason, R.P.; Bridson, P.K. Microsomal reduction of 3-amino-1,2,4-benzotriazine 1,4-dioxide to its free radical. Mol. Pharmacol. 1991, 40, 440-445.

18. Hay, M.P.; Gamage, S.A.; Kovacs, M.S.; Pruijn, F.B.; Anderson, R.F.; Patterson, A.V.; Wilson, W.R.; Brown, J.M.; Denny, W.A. Structure-activity relationships of 1,2,4-benzotriazine 1,4-dioxides as hypoxia-selective analogues of tirapazamine. J. Med. Chem. 2003, 46, 169-182. [CrossRef]

19. Hicks, K.O.; Siim, B.G.; Jaiswal, J.K.; Pruijn, F.B.; Fraser, A.M.; Patel, R.; Hogg, A.; Liyanage, H.D.S.; Dorie, M.J.; Brown, J.M.; et al. Pharmacokinetic/pharmacodynamic modeling identifies SN30000 and SN29751 as tirapazamine analogues with improved tissue penetration and hypoxic cell killing in tumours. Clin. Cancer Res. 2010, 16, 4946-4957. [CrossRef]

20. Gu, Y.; Chang, T.T.-A.; Wang, J.; Jaiswal, J.K.; Edwards, D.; Downes, N.J.; Liyanage, H.D.S.; Lynch, C.R.H.; Pruijn, F.B.; Hickey, A.J.R.; et al. Reductive metabolism influences the toxicity and pharmacokinetics of the hypoxia-targeted benzotriazine di-oxide anticancer agent SN30000 in mice. Front. Pharmacol. 2017, 8, 531. [CrossRef]

21. Zarranz, B.; Jaso, A.; Aldana, I.; Monge, A. Synthesis and anticancer activity evaluation of new 2-alkylcarbonyl and 2-benzoyl-1-trifluoromethyl-quinoxaline-1,4-di-N-oxide derivatives. Bioorg. Med. Chem. 2004, 12, 3711-3721. [CrossRef] [PubMed]

22. Chowdhury, G.; Sarkar, U.; Pullen, S.; Wilson, W.R.; Rajapakse, A.; Fuchs-Knotts, T.; Dates, K.S. DNA strand cleavage by the phenazine di- $\mathrm{N}$-oxide natural product myxin under both aerobic and anaerobic conditions. Chem. Res. Toxicol. 2012, 12, 197-206. [CrossRef] [PubMed]

23. Vicente, E.; Lima, L.M.; Bongard, E.; Charnaud, S.; Villar, R.; Solano, B.; Burguete, A.; Perez-Silanes, S.; Aldana, I.; Vivas, L.; et al. Synthesis and structure-activity relationship of 3-phenylquinoxaline 1,4-di-N-oxide derivatives as antimalarial agents. Eur. J. Med. Chem. 2008, 43, 1903-1910. [CrossRef] [PubMed]

24. Barea, C.; Pabon, A.; Perez-Silanes, S.; Galiano, S.; Gonzalez, G.; Monge, A.; Deharo, E.; Aldana, I. New amide derivatives of quinoxaline 1,4-di- $\mathrm{N}$-oxide with leishmanicidal and antiplasmodial activities. Molecules 2013, 18, 4718-4727. [CrossRef] [PubMed]

25. Cheng, G.; Sa, W.; Cao, C.; Guo, L.; Hao, H.; Liu, Z.; Wang, X.; Yuan, Z. Quinoxaline 1,4-di-N-oxides: Biological activities and mechanisms of action. Front. Pharmacol. 2016, 7, 64. [CrossRef]

26. Marcus, R.A.; Sutin, N. Electron transfers in chemistry and biology. Biochim. Biophys. Acta 1985, 811, $265-322$. [CrossRef]

27. Anderson, R.F.; Shinde, S.; Hay, M.P.; Denny, W.A. Potentiation of the cytotoxicity of the anticancer agent tirapazamine by benzotriazine-N-oxides: The role of redox equilibria. J. Am. Chem. Soc. 2006, 128, 245-249. [CrossRef]

28. Čènas, N.K.; Marcinkevičienè, J.A.; Kulys, J.J.; Usanov, S.A. A negative cooperativity between NADPH and adrenodoxin on binding to NADPH:adrenodoxin reductase. FEBS Lett. 1990, 259, 338-340. [CrossRef]

29. Marcinkevičienè, J.; Čènas, N.; Kulys, J.; Usanov, S.A.; Sukhova, N.M.; Selezneva, I.S.; Gryazev, V.F. Nitroreductase reactions of the NADPH: Adrenodoxin reductase and the adrenodoxin complex. Biomed. Biochim. Acta 1990, 49, 167-172.

30. Wardman, P. Reduction potentials of one-electron couples involving free radicals in aqueous solution. J. Phys. Chem. Ref. Data 1989, 18, 1637-1755. [CrossRef]

31. Čènas, N.; Anusevičius, Ž.; Bironaitè, D.; Bachmanova, G.I.; Archakov, A.I.; Öllinger, K. The electron transfer reactions of NADPH:cytochrome P450 reductase with nonphysiological oxidants. Arch. Biochem. Biophys. 1994, 315, 400-406. [CrossRef] [PubMed]

32. Anusevičius, Ž.; Martinez-Julvez, M.; Genzor, C.G.; Nivinskas, H.; Gomez-Moreno, C.; Nivinskas, H.; Čènas, N. Electron transfer reactions of Anabaena PCC 7119 ferredoxin: NADP $^{+}$reductase with nonphysiological substrates. Biochim. Biophys. Acta 1997, 1320, 247-255.

33. Lind, J.; Shen, X.; Merenyi, G.; Jonsson, B.Ö. Determination of the rate constant of self-exchange of the $\mathrm{O}_{2} / \mathrm{O}_{2}{ }^{--}$couple in water by ${ }^{18} \mathrm{O} /{ }^{16} \mathrm{O}$ isotope marking. J. Am. Chem. Soc. 1989, 111, 7654-7655. [CrossRef]

34. Anusevičius, Ž.; Šarlauskas, J.; Čènas, N. Two-electron reduction of quinones by rat liver NAD(P)H: Quinone oxidoreductase: Quantitative structure-activity relationships. Arch. Biochem. Biophys. 2002, 404, 254-262. [CrossRef] 
35. Misevičienè, L.; Anusevičius, Ž.; Šarlauskas, J.; Čènas, N. Reduction of nitroaromatic compounds by NAD(P)H: Quinone oxidoreductase (NQO1): The role of electron-accepting potency and structural parameters in the substrate specificity. Acta Biochim. Pol. 2006, 53, 569-576. [PubMed]

36. Mendoza, M.F.; Hollabaugh, N.M.; Hettiarachchi, S.U.; McCarley, R.L. Human NAD(P)H: Quinone oxidoreductase type I (hNQO1) activation of quinone propionic acid trigger groups. Biochemistry 2012, 51, 8014-8026. [CrossRef]

37. Nemeikaitè-Čènienè, A.; Jarašienè, R.; Nivinskas, H.; Šarlauskas, J.; Čènas, N. Cytotoxicity of anticancer aziridinyl-benzoquinones in murine hepatoma MH22a cells: The properties of RH1-resistant subline. Chemija 2015, 26, 46-50.

38. O'Brien, P.J.; Wong, W.C.; Silva, J.; Khan, S. Toxicity of nitrobenzene compounds toward isolated hepatocytes: Dependence on reduction potential. Xenobiotica 1990, 20, 945-955. [CrossRef]

39. O'Brien, P.J. Molecular mechanisms of quinone cytotoxicity. Chem. Biol. Interact. 1991, 80, 1-41.

40. Nemeikaitè-Čènienè, A.; Šarlauskas, J.; Anusevičius, Ž.; Nivinskas, H.; Čènas, N. Cytotoxicity of RH1 and related aziridinylbenzoquinones: Involvement of activation by $\mathrm{NAD}(\mathrm{P}) \mathrm{H}$ :quinone oxidoreductase (NQO1) and oxidative stress. Arch. Biochem. Biophys. 2003, 416, 110-118. [CrossRef]

41. Öllinger, K.; Brunmark, A. Effects of hydroxyl substituent position on 1,4-naphthoquinone toxicity to rat hepatocytes. J. Biol. Chem. 1991, 266, 21496-21503. [PubMed]

42. Hubig, S.M.; Rathore, R.; Kochi, J.K. Steric control of electron transfer. Changeover from outer-sphere to inner-sphere mechanism in arene/quinone redox pairs. J. Am. Chem. Soc. 1999, 121, 617-626. [CrossRef]

43. Raabe, J.; Arend, C.; Steinmeier, J.; Dringen, R. Dicumarol inhibits multidrug resistance protein 1-mediated export processes in cultured primary rat astrocytes. Neurochem. Res. 2019, 44, 333-346. [CrossRef] [PubMed]

44. Buffinton, G.D.; Öllinger, K.; Brunmark, A.; Cadenas, E. DT-diaphorase-catalysed reduction of 1,4-naphthoquinone derivatives and glutathionyl-quinone conjugates. Effects of substituents on autoxidation rates. Biochem. J. 1989, 257, 561-571. [CrossRef] [PubMed]

45. Ishihara, Y.; Shiba, D.; Shimamoto, N. Enhancement of DMNQ-induced hepatocyte toxicity by cytochrome P 450 inhibition. Toxicol. Appl. Pharmacol. 2006, 214, 109-117. [CrossRef]

46. Anusevičius, Ž.; Šarlauskas, J.; Nivinskas, H.; Segura-Aguilar, J.; Čènas, N. DT-diaphorase catalyzes $\mathrm{N}$-denitration and redox cycling of tetryl. FEBS Lett. 1998, 436, 144-148.

47. Kurokawa, H.; Ito, H.; Inoue, M.; Tabata, K.; Sato, Y.; Yamagata, K.; Kizaka-Kondoh, S.; Kadonosono, T.; Yano, S.; Inoue, M.; et al. High resolution imaging of intracellular oxygen concentration by phosphorescence lifetime. Sci. Rep. 2015, 5, 10657. [CrossRef]

48. Zeman, E.M.; Baker, M.A.; Lemmon, M.J.; Pearson, C.I.; Adams, J.A.; Brown, J.M.; Lee, W.W.; Tracy, M. Structure-activity relationships for benzotriazine di-N-oxides. Int. J. Radiat. Oncol. Biol. Phys. 1989, 16, 977-981. [CrossRef]

49. Long, D.J., II; Iskander, K.; Gaikwad, A.; Arin, M.; Roop, D.R.; Knox, R.; Barrios, R.; Jaiswal, A.K. Disruption of dihydronicotinamide riboside:quinone reductase 2 (NQO2) leads to myeloid hyperplasia of bone marrow and decreased sensitivity to menadione toxicity. J. Biol. Chem. 2002, 247, 46131-46139. [CrossRef]

50. Kirkland, D.; Marzin, D. An assessment of the genotoxicity of 2-hydroxy-1,4-naphthoquinone, the natural dye ingredient of Henna. Mutat. Res. 2003, 537, 183-199. [CrossRef]

51. Pechurskaja, T.A.; Harnastai, I.N.; Grabovec, I.P.; Gilep, A.A.; Usanov, S.A. Adrenodoxin supports reactions catalyzed by microsomal steroidgenetic cytochrome P450s. Biochem. Biophys. Res. Commun. 2007, 353, 598-604. [CrossRef] [PubMed]

52. Prochaska, H.J. Purification and crystallization of rat liver NAD(P)H:quinone-acceptor oxidoreductase by cibacron blue affinity chromatography: Identification of a new and potent inhibitor. Arch. Biochem. Biophys. 1988, 267, 529-538. [CrossRef]

53. Ito, M. Microassay for studying anticellular effects of human interferons. J. Interferon Res. 1984, 4, 603-608. [CrossRef] [PubMed]

(C) 2019 by the authors. Licensee MDPI, Basel, Switzerland. This article is an open access article distributed under the terms and conditions of the Creative Commons Attribution (CC BY) license (http://creativecommons.org/licenses/by/4.0/). 